\title{
Core Employees' Impact on the Performances of Turkish Large Firms: A Research in the Frame of the Resource-Based View of the Firm
}

\author{
Kurtuluş Yılmaz Genç ${ }^{1}$ \\ ${ }^{1}$ Giresun University, Faculty of Economics and Administrative Sciences, Giresun, Turkey \\ Correspondence: Kurtuluş Yılmaz Genç, Giresun University, Faculty of Economics and Administrative Sciences, \\ Giresun, Turkey. Tel: 90-534-212-2951. E-mail: kyilmazgenc@gmail.com
}

Received: October 9, 2014

Accepted: October 21, $2014 \quad$ Online Published: November 22, 2014

doi:10.5539/ijbm.v9n12p74

URL: http://dx.doi.org/10.5539/ijbm.v9n12p74

\begin{abstract}
The basic aim of this study is to explore the impact of core employees on organizational performance with a research conducted on Turkish large firms. Core employees were taken as the personnel, working at the production functions of firms, and their role were examined in frame of the resource-based view. Survey forms were developed by international literature review and sent to top 500 firms of Turkey for 2010, which were determined by Istanbul Chamber of Commerce (ISO). This study reveals statistically significant relation between value and uniqueness and inimitability levels of core employees and organizational performance, innovation, strategic vision, flexible design, quality orientation, organizational culture, providing employee potential, and product diversity; as a reflection of resource-based view of the firm. Moreover, the analysis of data revealed the value of core employees is more effective than their uniqueness on organizational performances. This research also indicates the valuable and unique human resources of top Turkish firms as one of the basic elements that lead to competitive advantage.
\end{abstract}

Keywords: core employees, resource-based view, organizational performance, Turkish large firms

\section{Introduction}

The aim of this study is to examine the impact and the role of core employees on the performances of Turkish large firms. It focuses on whether the value, rareness, inimitability, and organization of the core employees are related with organizational performance and various organizational characteristics and implementations as managerial, organizational, and output-based capabilities in the light of the resource-based view (RVB) and studies by Barney (1986, 1991, 1995, 2001), Barney and Wright (1998), Lepak and Snell (1999, 2002), Lado and Wilson, 1994; Lepak, Takeuchi, and Snell (2003); Lopez-Cabrales, Valle, Herrero (2006); and Wright, McMahan, MacWilliams (1993). Data was gathered with a survey conducted on the largest 500 firms of Turkey. The population was 500 and the sample was 79 .

This study investigates the importance of core employees for the performances of Turkish large firms, in Today's turbulent business environment. It is mainly based on the VRIO (value, rareness, inimitability, organization) framework, which was applied to core employees. So, the value, uniqueness, inimitability, organization of core employees and organizational performance relationship is examined. In addition, the association between value, uniqueness and innovation and product variety is also discussed. Moreover, the correlation between managerial capabilities, such as 'reinforcement of the organizational culture', 'strategic vision', 'obtaining employee potential', 'flexible design', and value and uniqueness of core employees were examined. Equally, technical capability of innovation, and output-based capabilities, such as 'quality orientation' and 'product diversity' were evaluated for their association with the qualifications of core employees. Accordingly, in the first part of the paper, related literature is discussed. Then, in the second part, the results of the field research are given and discussed; and finally, a general conclusion is presented.

\subsection{Resource-Based View and Core Employees}

Resource-based view (RBV) focuses on the importance of owning rare, unique and valuable resources and competencies (Collis \& Montgomery, 1995; Lopez-Cabrales, 2006; Prahalad \& Hamel, 1990) that stated to be the source of sustainable competitive advantage (Barney, 1991; Barney \& Wright, 1998; Lopez - Cabrales, Valle, Herrero, 2006; Wright, McMahan, \& McWilliams, 1994). Human resources as a source of competitive 
advantage was examined by many writers (e.g. Barney \& Wright, 1998; Lado \& Wilson, 1994; Lopez-Cabrales et al., 2006; Snell, Youndt, \& Wright, 1996; Wright et al., 1994) in the frame of resource-based view. Human resource was pointed out among the major sources of sustained competitive advantage for a firm: physical capital resources (e.g. plant, equipment, and finances), organizational capital resources (e.g. firm's structure, planning, controlling, and coordinating) and HR (Barney \& Wright, 1998).

\subsection{Competitive Advantage and Sustained Competitive Advantage with Human Resources}

Barney (1991, pp. 105-112) explains that resources that can let a firm to achieve competitive advantage have four basic characteristics: "(a) it must be valuable, in the sense that it exploit opportunities and/or neutralizes threats in a firm's environment, (b) it must be rare among a firm's current and potential competition, (c) it must be imperfectly imitable, and (d) there cannot be strategically equivalent substitutes for this resource that are valuable but neither rare or imperfectly imitable." Resources are valuable when they increase productivity, efficiency, and performance; and for this exploiting opportunities and neutralizing threats is also necessary. Rareness implies the resources which are specific to a firm by barriers for mobility or accessibility. Rare resources facilitate firms to gain a competitive advantage. The competitive advantage is also a consequence of imperfectly imitable resources. Firms might gain and especially sustain competitive advantage by this characteristic of a resource. Imperfectly imitability can be a result of unique historical conditions, casually ambiguity, and social complexity. Unique historical conditions imply to be in the right place or situation at the right time to have and exploit resources that can be used to achieve competitive advantage. By this way, firms can have valuable and rare resource that other firms could not own. If other firms don't understand which resources of the firms lead the competitive advantage they won't have the chance to imitate it. This situation is known as causal ambiguity about imperfectly imitable resources. Accordingly, it is about not to be able to catch the link between the competitive advantage and the creator resource. Social complexity is about the composition and sum of many different items of a firm's internal and external environment in terms of history, traditions, values and other cultural elements, human resources, physical conditions or structure, name, brand; location, market, public image, relations. It is impossible to imitate or duplicate this very complex structure, a competitive advantage emerges conveniently. Finally, substitutability is about existence of equivalent valuable resources that can be used to realize same strategies by competitive firms. However, substitutability is rarely related and examined in the frame of human resource function, in the literature.

Based on the studies of Barney (1991; 1995), Wernerfelt (1984), and Dierickx and Cool (1989), Barney and Wright (1998) examined the VRIO framework for human resource of a firm. VRIO implies value, rareness, inimitability, and the organization of HR. Accordingly, the 'substitutability' of any internal element of resource-based view, was changed with the 'organization'.

\subsection{The Value of Human Resource}

Human resource can be the source of sustained competitive advantage, only if they provide value to the firm (Wright, McMahan, McWilliams, 1993). So, how can valuable human resources are defined? Barney and Wright (1998) discussed the value of human resources and stated that it is about "decreasing product/service costs or differentiating the product service in a way that allows the firm to charge a premium price" $(1998$, p. 5). Therefore, the value of human resources should be measured for their contribution to lowering costs and increasing market prices of products or services. These scholars emphasis on that value can be "created by focusing on employees first"(Barney \& Wright, 1998, p. 5). Hence, if employee satisfaction can be provided then it will be easy to satisfy customers, so minimize costs to maximize sales and income, achieve and maintain high quality levels and create value (Barney \& Wright, 1998; Lepak, \& Snell, 2002; Wright et al., 1993). Thus, HRM practices should be generated in the best way to achieve this conclusion. Similarly, Tornow and Wiley (1991) found that there had had a relationship between the organizational performance and employee behavior like job satisfaction. Barney and Wright (1998) imply that revenues increase employee morale and so employee satisfaction.

Barney and Wright (1998) emphasize that sustainable competitive advantage depends on especially firm specific skills. General skills cannot be the source of competitive advantage. Scholars discussed that general skills will not provide a competitive advantage to any firm, but the absence of the general skills will result in a disadvantage in the industry and competitiveness. Moreover, scholars state that investing on general skills is also needed to attract and retain competent employees. Finally, scholars discussed that it is possible to gain competitive advantage with the highest level of general skills.

In general, efficiency can be defined as the output gained from limited or fewer resources. So, as a performance criterion, efficiency (productivity) can be increased through achieving same output from fewer resources, and 
taking more output from given resources (Hamel \& Prahalad, 1993). So, valuable human resource could be able to distinguish a firm from its competitors by increasing efficiency, creating innovation, achieving quality in customer service (Beardwell \& Claydon, 2011; Lundy \& Cowling, 1996; Mello, 2006). The contribution of human resources to the firms' financial structure can also be seen in the increased value of shares in the stock market.

On the whole, valuable human resource, strengthen the competitiveness of a firm. Besides, qualified employees would facilitate strategy design and implementation. So, if the core employees of a firm are valuable, then the quality of manufacturing process and products would be higher, which will result in customer satisfaction.

\subsection{The Rareness of Human Resource}

The rareness of human resource can lead a firm to competitive advantage (Beardwell \& Claydon, 2011; Barney, 1991; 1995; Barney \& Wright, 1998: 42; Lado \& Wilson, 1994; Wright et al., 1993). Valuable but common human resources may just provide a competitive equity to a firm, but for a competitive advantage rareness is needed. It depends on heterogeneity of the resources in an industry which gives an advantage to just one firm and prevents other firms' to own it. This type human resource may be a base for an organization, just because of that prevention.

Wright et al. (1993), argued that, organizations which have higher levels of 'cognitive ability' than their competitors, posses more human capital, which can lead competitive advantage. Accordingly, cognitive ability can be related to organizational performance.

The core employees of firms may lead the competitive advantage if they are rare and human resource mobility is not an easy movement in that industry. Highly qualified manufacturing department employees with their excellent, unique skills and abilities, their extraordinary design, creation and implementation power in invention or production are capable of carrying their firms to the competitive advantage position and as a result to a high organizational performance level.

Rareness can be the result of highly qualified core employees besides the supporting organizational culture of tolerance, liberty, incentive rewards or difficulty of other firms to achieve these brilliant employees.

\subsection{The Inimitability of Human Resource}

Valuable and rare human resources can be the source of competitive advantage in the long term, but just if these qualities are inimitable. In other words, imitable characteristics can only provide short term advantage, which means competitive parity (Beardwell \& Claydon, 2011; Barney, 1995; Barney \& Wright, 1998; Lado \& Wilson, 1994; Wright et al., 1993).

Inimitability is the third element of the VRIO framework (Barney, 1991; 1995; Barney \& Wright, 1998; Wright et al., 1993). Scholars stated that human resources should be imperfectly imitable in order to provide a competitive advantage to a firm. The human resource that can be imitable easily could not result in a competitive advantage. It was also emphasized that unique historical and cultural characteristics of a firm may be the base for an imperfectly imitable organizational resource or the human resources. Unique historical experiences and unique cultural structure cannot be imitated by other firms and may make it possible to achieve a competitive advantage.

Resources can be imitated by competitors, if they can achieve the source of competitive advantage. Also, many components of human resource of a firm, and related conditions should be duplicated (Wright et al., 1993).

The core employees of a firm working in the manufacturing function need to be inimitable to lead competitive advantage if other variables are constant. Unique historical conditions and cultural structure may be the base for the unique core employees. The cumulated knowledge of production department might make core employees inimitable in designing, creating, or inventing new and diversified products or services. The cultures of tolerance and liberty which can be efficient with responsible, highly qualified employees also might create an imperfectly imitable human resource and core employee type.

\subsection{The Organization of Human Resource}

Finally, the VRIO framework proposes that, human resource of a firm should be organized to be a source of sustainable competitive advantage, which is based on adding value, rarity, and inimitability. Accordingly, HR systems should be integrated coherently to achieve such a position. In the same way, companies should be organized to capitalize on these resources to maintain competitive advantage (Beardwell \& Claydon, 2011; Barney \& Wright, 1998). 


\subsection{VRIO Framework for Core Employees}

Core employees with their unique qualifications might lead a competitive advantage. Accordingly, with their high levels of skills, abilities and knowledge, they may increase the efficiency, productivity, and performance of their firms, and; by this way they present their value. An organizational environment in which mobility is spontaneously prevented rareness would be protected as a base that may lead a competitive advantage. If other firms cannot understand the link between valuable, rare, unique core employees and competitive advantage than they will not attempt to imitate it. This casual ambiguous situation may be a base for competitive advantage depending on human resources which cannot be imitative.

Core employees and their value, rareness, inimitability and organization are all a part of a complex structure of that firm which is impossible to duplicate. Specific historical conditions, organizational culture, physical structure and business environment create this unique complexity and it strengthens core employees' rareness which may generate competitive advantage.

In a firm, human resource is the base to coordinate all other resources in accordance with organizational strategy or purposes. Hence, core employees structure a firm's future with their productivity, creativity, and all types of skills, abilities and knowledge. This basical resource both affects all these items of an organization's internal and external environment and being affected by all them.

"A firm is said to have competitive advantage when it is implementing a value creating strategy not simultaneously being implemented by any current or potential competitors. A firm is said to have sustained competitive advantage when it is implementing a value creating strategy not simultaneously being implemented by any current or potential competitors and when these other firms are unable to duplicate the benefits of this strategy" (Barney, 1991; p. 102). Accordingly, Human resources that have valuable, rare, and imperfectly imitable qualifications may lead a firm to a sustained competitive advantage. A firm should have valuable and unique human resources or core employees to achieve a competitive advantage; and for a sustainable competitive advantage, other firms must be unable to imitate these core employees perfectly them. The core employees with their unique skills, abilities, knowledge, and creativeness can easily provide a strong pioneering in business and further a competitive advantage. This is a consequence of capability in design and innovation, management and public relations.

As discussed by Barney $(1991 ; 1995)$ resources are also to be needed as immobile and heterogenic to lead competitive advantage. Homogeneity implies identity and mobility presents easily distributable sources. Homogeny resources in an industry can not be the source of competitive advantage because of its generality, and ordinarily situation; in terms of accessibility to the resources by all of the firms of the sector. Firms should also implement different strategies for a significant heterogeneity and immobility.

If in an industry, a firm has various types of human resources in terms of skills, abilities, intelligence, as a sum of qualifications, then; this means that there is a human resources heterogeneity which may lead a firm to competitive advantage with human resource immobility. In a heterogenic and immobile industry in terms of human resources, it might be easy for firms to compete in a strong level and further; achieve the competitive advantage which could depend on unique and high quality human resources. The indirect barriers to human resources mobility may be the level of salary, or the conditions of the job environment.

When, resourced-based view integrated human resource management (HRM), a "human capital advantage" is identified through recruiting and retaining extraordinary human skills and ability. This type of human resource is valuable and cannot be imitated easily by other firms (Barney \& Wright, 1998; Boxall, 1996; Lopez-Cabrales et al., 2006). HRM is being discussed as a "proxy variable" of competitive advantage. These types of competencies are unique to each firm, and they are the basis of socially complicated relations, which can be found in the history and the cultures of firms, that creates implicit organizational knowledge (Barney, 1991; Lado \& Wilson, 1994; Lopez-Cabrales et al., 2006; Reed \& De-Filippi, 1990). HRM also supports the activities which gives identity, innovation, or quality orientation to a firm (Lado \& Wilson, 1994; Lopez-Cabrales et al., 2006; Wright, McMahan, \& McWilliams, 1994).

According to resource-based view only the employees who are valuable, rare, unique, and organized in the right way can be the source of competitive advantage (Lopez-Cabrales et al., 2006: 82; Barney \& Wright, 1998). Firms might achieve human capital advantage directly by recruiting and retaining extraordinary employees (Lopez-Cabrales et al., 2006; Boxall, 1996). Valuable, rare, unique, inimitable and properly organized employees may lead competitive advantage. 
Human resources operations advantage, in a way, is a combination of causally ambiguous, societally complicated human resources policies and practices which are historically developed. HRM implementations should be integrated with the skills, abilities, vision and the demands of employees (Boxall, 1996; Lopez-Cabrales et al., 2006).

A core employee is generally characterized as valuable and unique and as the person who is the major part of the core activity and performs the basical operations or competencies of a firm (Atchison, 1991; Lopez-Cabrales et al., 2006; Prahalad \& Hamel, 1990). According to Osterman (1994, p. 175) that core employees can be recognized as: "the largest group of non-supervisory, non-managerial workers involved in making the product or in providing a service."

Prahalad and Hamel (1990) argued that, the core competencies of firms can give distinctive advantage in their industries, in terms of competition. It is obvious that, core competencies are directly associated with the uniqueness of core employees. In relation to this, Lopez-Cabrales et al. (2006) found that core employees are positively related with the very valuable human capital.

H1: The value of core employees is positively associated with the uniqueness of human capital.

The second basical characteristics of core employees might be uniqueness. The impact of core employees on organizational performance and in the process of gaining competitive advantage is directly related with the level of uniqueness. Uniqueness is a required qualification for gaining competitive advantage for especially high-tech firms. Uniqueness is also discussed as a point of implicit competency. Uniqueness is not suggested as a required characteristic for core employees (Barney, 1991; Lopez-Cabrales et al., 2006; Teece, Pisano, Shuen, 1997; Snell, Youndt, \& Wright, 1996; Wright \& McMahan, 1992).

Lopez-Cabrales (2006) presented that core employees are not associated with the uniqueness of human capital.

Resource-based view has emerged, developed in strategic management approach, and has integrated with the other areas of management through the time. When the traditional competition elements/sources had became attainable for all firms, it has appeared to be a necessity to own rare, unique, imperfectly imitable resources which also don't have strategically equivalent substitutes; for firms. When RBV is integrated with human resources management (HRM); the most important resource as the focus of resource-based view and the source of competitive advantage for firms is human resources. When it is evaluated together with human resources management, it is human resources that is focused on by resource-based view and that will provide competitive advantage to a firm. Any firm that has rare, unique, imperfectly imitable resources which don't have strategically equivalent substitutes may easily have competitive advantage in today's complicated, rapidly changing, and developing competitive atmosphere. 'Core employees' have the dominant role for the success of the firm as a part of human resources. In this study, 'core employees' will be taken as the employees who are working at the production or core department of the firms. Core employees with their specialization, skills, abilities and qualifications are the basic business resources that will lead a firm to achievement of its purposes. The contribution of core employees to their firms will increase, when they have qualifications that are valuable, rare, inimitable, and if they are well organized; so they will provide sustainable competitive advantage to their firms. International literature on this topic presents supporting evidence (e.g. Delaney-Huselid, 1996; Hart, 2005; Harel-Tzafrir, 1999; Hester, 2005; Liqun, 2004; Lopez-Cabrales et al., 2006; Takeuchi, 2003; Wright-MacMahan, 1992; Youndt, Snell, Dean, \& Lepak, 1996; Youndt, 2001). Lopez-Cabrales et al. (2006) found that, firms which are using the most valuable and unique employees have the highest efficiency level. Lepak, Takeuchi, and Snell (2003) found that, knowledge-based employment is associated with firm performance. Erdil, Kitapç1, and Timurlenk (2010) achieved the result that, the value of core employees is positively related with firm performance. Lopez-Cabrales (2006) found that "firms with very valuable and very unique core employees will be more efficient than other firms with different kinds of core employees". In what scale the qualifications of the core employees are different, rare, or unique; their effects on organizational performance and output shall be in that rate, in a positive way. The core employees who have higher level of qualifications would have higher level of impacts on organizational performance. It can be estimated that, the level of impacts of core employees on organizational performance and would related to their level of qualifications in terms of value, rareness, inimitability, and organization at Turkish large firms. In other words, it would be a fully realistic approach to predict that this situation can be seen at the practices of Turkish large firms. Hence, the basic hypothesis of this study is:

H2: There is a positive relationship between the qualifications of core employees in terms of value, rareness, inimitability, and organization and the performances of Turkish large firms.

The other hypotheses of this study are as follows: 
Wright et al. (1993) argue that, the effectiveness of human resource can be change according to environmental conditions. Accordingly, in turbulent environments, human resources should be more dynamic to respond developments, or to be proactive. In contrast, static environments can make human resource more efficient. Moreover, in dynamic and complex environments, human resource can develop the ability to respond environmental requirements, which make firms more effective. So, this can be related to industries, in which, companies operate. Therefore, the impacts of core employees can be expected to be differentiating according to the industries which the firms are operating in. There is a high possibility that core employees would be more effective in high technology, invention, and manufacturing firms than other sectors of firms. Thus:

Hypothesis 3 (H3):

Hypothesis 3_0: The means of the value of core employees would not change according to industry type.

Hypothesis 3_1: The means of the value of core employees would change according to industry type.

The level of qualifications of core employees in terms of value, rareness, and being properly organized would lead them to be succeeding in innovation operations. Innovation activities require advanced skills and abilities to be creative, and respond to the necessities of the field. Thinking in different types, to see and recognize opportunities, demands, needs, and absences; to come up with different, unique solutions, original suggestions are essential qualifications for the innovation operations. The emergence of such characteristics in a structure special to each firm also reflects the basic approach of the resource-based view.

H4a: There is a positive relationship between the value of core employees, and innovation implementations of Turkish large firms.

H4b: The uniqueness and inimitability of core employees of Turkish large firms are significantly and positively correlated with their innovation implementations.

Similarly, it can be expected that these characteristics would affect the product variety. In other words; core employees who can think in a diverse manner, who have a broad horizon, who are creative, intelligent or clever that are special for a firm would be able to design and produce various types of outputs. This also will allow the re-testing of the hypothesis related with innovation. In the same way, Erdil et al. (2010) identified a positive and statistically significant relation between the value of core employees and technical capabilities and output based capabilities, such as quality orientation, customer loyalty, and product diversity; in a research, which was realized in Turkey. Therefore, it can be proposed that:

H5a: The value of core employees will be positively and significantly correlated with the product variety of Turkish large firms.

H5b: The rareness and inimitability of core employees will be positively associated with the product variety of Turkish large firms.

Qualified core employees with their high levels of creativeness, intelligence, specialization on their areas or functions, to be perceived as among the best employees of the sector, to be able to design new thought, knowledge and product would allow them to increase organizational performance. Erdil et al. (2010) revealed a positive and statistically significant relation between the value of core employees and firm performance. Then, for Turkey, it can be estimated that:

H6: There is a positive relationship between the high level qualifications of the core employees and the organizational performances of the Turkish large firms.

In this study, flexibility of the organizational structure includes the elastic design of the jobs, the coherence of the organizational culture to the changes in the business environment, easily activation of human resources by physical, financial and intangible resources, getting away from centralization, and obtaining secondary functions from the outside (or other firms) (Lopez-Cabrales et al., 2006). Flexible design at the firms might provide employee's more easily presentation of their abilities. Thus, elastic design would facilitate manufacturing of the product variety.

H7: There is positive relationship between the flexible design and the product variety of the Turkish large firms.

Culture is directly related with the organizational design. Furthermore, culture is very important to motivate employees, and direct them for the specific purposes. Moreover, organizational culture with its items contributes value, rareness, nonsubstitutability, and difficulty to replication of employees' qualifications.

Barney (1986) argues that organizational culture that is valuable, rare, and imperfectly imitable may lead competitive advantage (Barney, 1986; Lado \& Wilson, 1994). Similarly, Lado, Boyd, and Wright (1992) pointed 
out the importance of organizational culture for competitive advantage. As mentioned above, culture support strategic changes or resist to it. So, flexibility, being innovative, and rationalism are important for implemented strategy; and they facilitate organizational success (Cook, Hunsaker, 2001; Wright, Kroll, Parnell, 1998).

Employees who work in a valuable and unique culture can be expected to have valuable, rare and imitable skills. The qualifications of core employees should be associated with the characteristics of an organizational culture, in terms of an atmosphere which supports creativity, vision, and uniqueness. Therefore, core employees with these qualifications will contribute to the process in which firms gain competitive advantage.

As Lopez-Cabrales et al. (2006) searched for; an organizational culture in which: managers communicate affectively or transmit shared values; employees can identify the shared values and integrate themselves. At an organization like this, there are just a few examples for operations of the employees' prejudice to the shared values. At this type organizations' employees' harmonic behaviors are rewarded; and managers supports employees to achieve organizational purposes.

H8: The qualifications of core employees will be positively and significantly correlated with organizational culture.

Basic contribution of this study would be arguing the importance of core employees and their impact on organizational performance in the frame of resource-based view.

\section{Previous Studies}

In their study Lopez-Cabrales et al. (2006, p. 101) searched the relationship between core employees and organizational capabilities, and efficiency; and found that "very valuable and very unique core employees are associated with competitiveness and efficiency".

\subsection{Core Employees and Organizational Capabilities}

This part of this study was generally adapted from the studies of Lopez-Cabrales (2006) in terms of the view. Organizational capabilities were classified as managerial capabilities, technical capabilities, and out based capabilities for their orientation (Erdil et al., 2010; Lopez-Cabrales, 2006; Turner \& Crawford, 1994).

\subsection{Managerial Capabilities}

A managerial capability is defined as the competence to design a common strategic vision, and identity for the organization; stimulate the personnel to accomplish them and to organize various functions and departments. There are four types of basic managerial capabilities examined in the literature: "reinforcement of the organizational culture", "strategic vision, and obtaining employee potential and "flexible design" (Lado \& Wilson, 1994; Lopez-Cabrales, 2006; Macduffie, 1995).

'Organizational culture' is a complex set of values, beliefs, assumptions, and symbols that define the way in which a firm conducts its business. Moreover, the leadership styles of top management, values and beliefs of members, structures organizational culture (Barney, 1986; Certo, 1997; Kreitner, Kinicki, 2004; Schermerhon, Hunt, 2000). Also, purposes and strategies influence culture (Mullins, 2002). Organizational culture defines a firm's stakeholders; as employees, competitors, suppliers, customers, and the way of firm's interaction with them. Willcoxson and Millett (2000) stated that; "an organization responds to and reflects industry characteristics such as the competitive environment and customer requirements, together with the wider community values held by its employees, and also the values and behaviors of its founders and early leaders" (Willcoxson \& Millett, 2000). A firm's culture must be consistent with that firm's competitive situation, by this way it can be a source of competitive advantage. In other words, organizational cultures should support strategic change; so, realize external adaptation and internal integration (Barney, 1986; Kreitner, Kinicki, 2004; Schermerhon, \& Hunt, 2000). An effective, strong organizational culture might be the source of a competitive advantage.

'Strategic vision' can be defined as 'the desired future position' (Raynor, 1998) of a firm. Vision also reflects the market of a firm (Raynor, 1998). Vision is a phase which includes manager's perceptions, evaluation, definition, explanation, sharing and intellectual processes and efforts about future operations and alternatives (Eren, 2002). The quality of a vision is also examined by Eren (2002): it is original for every manager and leader, it requires perception and evaluation of all the future operations, it will gain value when it is shared, it is the basic source for strategy and purposes, it also gives information about manager's and strategist's quality of creativeness, innovation, to accept a risk, to be a participator, and to share in. Ulgen and Mirze (2004) explains that an organizations mission statement consists of purposes, targets, and values; at the same time for public image. 
A unique strategic vision as an outcome of a specific organizational history, in terms of complicated conditions and experiences can be a source of competitive advantage (Lado \& Wilson, 1994; Lopez-Cabrales, 2006; Prahalad \& Hamel, 1990).

'Obtaining employee potential' is the competency of recruiting outstanding candidates and getting their high potential, in terms of skills and abilities to the firm (Lopez-Cabrales, 2006). High potential employees would be eager to fulfill the requirements of organizational purposes. Personnel who are ready to work for the vision of a firm, can also be supported by human resource management activities, like job analysis, rewards, empowerment, and career development (Lopez-Cabrales, 2006; Ulrich, 1994).

'Flexible design' is the operation especially to respond the rapidly changing or turbulent environments. Firms have to transform their inner organizing methods and work to adapt the environment to keep the firm efficient and profitable position or to increase them. Flexible design links human resource management practices to manufacturing practices (Hendersen \& Cockburn, 1994; Lopez-Cabrales, 2006; Macduffie, 1995; Nadler \& Tushman, 1999).

Lopez-Cabrales et al. (2006) found that very valuable and very unique core employees are positively related with managerial competencies for 'reinforcement of organizational culture', 'strategic vision', and 'obtaining employee potential'. However, same scholars could not find a supporting evidence for their hypothesis: very valuable and less unique core employees are positively associated with the managerial capability for flexible design.

Hypothesis 9a: Valuable and unique core employees are positively related with managerial capability for 'reinforcement of organizational culture'.

Hypothesis 9b: Valuable and unique core employees are positively related with managerial capability for 'strategic vision'.

Hypothesis 9c: Valuable and unique core employees are positively related with managerial capability for 'obtaining employee potential'.

Hypothesis 9d: Valuable and unique core employees are positively associated with the managerial capability for 'flexible design'.

\subsection{Technical Capabilities}

Technical capabilities simply reflect the competence in 'innovation'. Technical capabilities were discussed in the literature as the technological aspects of the creation, production, and development of products and services (Lopez-Cabrales, 2006; Macduffie, 1995). Prahalad and Hamel (1990) discussed the relation between innovation and core employees.

Macduffie (1995) suggests three major conditions for the contributions of human resource to organizational performance: Employees should have knowledge, which, managers don't posses; this knowledge and qualities should be put into practice by personnel with desire; if the strategy of an organization can only be implemented, so purposes achieved with the efforts of employees. In relation to this, Macduffie (1995) also found that, innovative HR practices affect organizational performance. As mentioned above, Erdil et al. (2010) achieved a positive and statistically significant relation between the value of core employees and technical capabilities.

Lopez-Cabrales (2006) found that "very valuable and very unique core employees are positively associated with the technical capability for innovation".

Hypothesis 10: Valuable and unique core employees are positively related with the technical capability for 'innovation'.

\subsection{Output-Based Capabilities}

Out-based capabilities are about designing or inventing tangible or intangible entities which might create value for consumers (Erdil et al., 2010; Lado \& Wilson, 1994; Lopez-Cabrales, 2006; Macduffie, 1995).

Out-based capabilities are reflected as 'quality orientation' and 'product diversity' in this study. These two competencies are might suggested to be linked with value, rareness, and inimitability of core employees. Personnel with high level qualifications can be expected to implement the quality at internal structure and all the processes of a firm.

Quality orientation with its context as continuous improvement, preventing faults at its source, attempts to achieve excellent level, setting up the high level quality as a sum in the whole firm would facilitate gaining the 
competitive advantage. Valuable and unique core employees would make easier to achieve the competitive advantage by setting up the quality.

Product diversity is a reflection of creativity mainly related with the competencies of the core employees. Diversified quality products that might lead competitive advantage require valuable and rare core employees.

Lopez-Cabrales (2006: 95-99) presented that "very valuable and very unique core employees are positively associated with out-based capabilities for "quality orientation" and "company-customer loyalty". On the other hand, same scholars could not find any statistical evidence for the hypothesis: "very valuable but less unique core employees are positively associated with the output-based capability for product diversity". And also, Erdil et al. (2010) identified a positive and statistically significant relation between the value of core employees and output based capabilities.

Hypothesis 11a: Valuable and unique core employees are positively related with the output-based capability for 'quality orientation'.

Hypothesis $11 \mathrm{~b}$ : Valuable and unique core employees are positively related with output-based capability for 'product diversity'.

\section{Methodology}

\subsection{Research Goal}

In this survey it was mainly aimed to identify the relation between the value, rareness, inimitability, and organization of core employees and organizational performance. Moreover, it was also aimed to demonstrate the relation between the qualities of core employees according to VRIO framework, and organizational, technical and managerial capabilities. In addition, the relation between sector and VRIO related variables are also examined. The ultimate goal of this paper is mainly to set light on the value, rareness, inimitability, and organization of core employees and organizational performance relation.

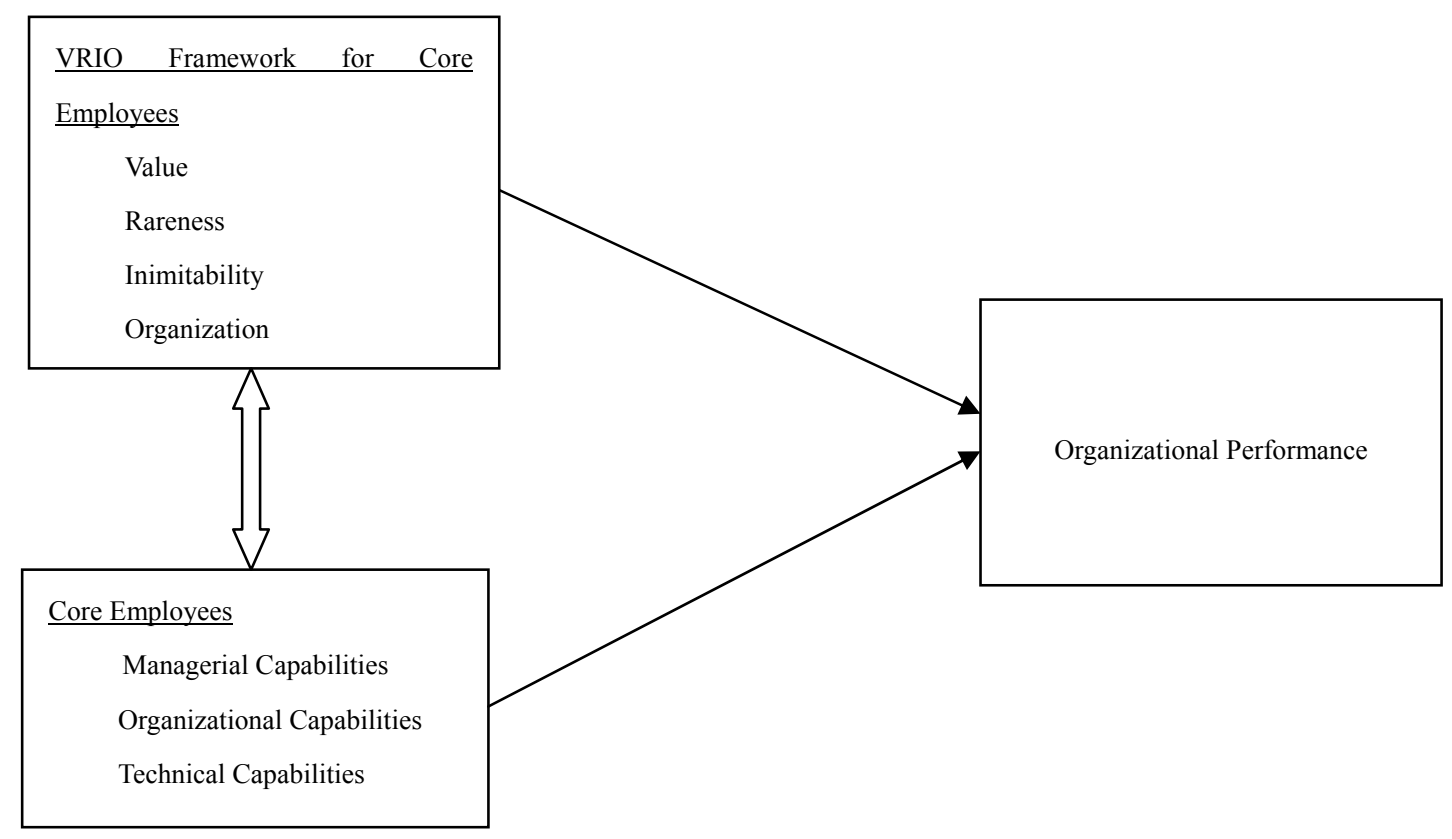

Figure 1. Research model for VRIO framework - organizational performance relation

\subsection{Sample and Data Collection}

This research was designed to demonstrate the importance of the core employees for firms, by presenting the relation between the qualifications of core employees with several implementations as innovation, strategic vision, flexible design, quality orientation, organizational culture, creating opportunities, product variety and organizational performance at Turkish large firms. Therefore, hypotheses were developed to analyze the topics which were given above. 'Core employees' were regarded as the personnel who are working at the basic function or at the distinctive activity of the firm (Atchison, 1991; Lopez-Cabrales et al., 2006). At the research 
process core employees were evaluated and measured for their qualifications, so skills and abilities; and uniqueness of qualities, accordingly specialty for a firm. In the research, fivefold Likert type scale was used $(1=$ strongly disagree; $5=$ strongly agree). Questions that were used in the survey were taken from international related literature (e.g. Youndt, 2001; Takeuchi, 2003; Lopez-Cabrales et al., 2006). Questions of the scale that was used to measure the uniqueness of core employees were taken from the study of Youndt (1998). The scale of the perceived organizational performance was collected from the studies of Delaney and Huselid (1996), Harel and Tzafrir (1999), Hester (2005), Liqun (2004), and Youndt et al. (1996). The questions for perceived market performance were adapted from Liqun (2004). The scales of 'innovation', 'strategic vision', 'flexible design', 'quality orientation', 'organizational culture', 'obtaining the employee potential', and 'product diversity'. Survey form was analyzed and evaluated as suitable for Turkey's business conditions, then; they were sent to top 462 firms of Turkey in terms of largeness, which were among top 500 firms that were determined by the Istanbul Chamber of Commerce (ISO). 79 of the survey forms were answered and turned back; so, the response rate is $15.8 \%$. Term for survey was December 2011 (Initial preparations for an early version of this study was realized in April-May 2011, but then process was stopped and delayed for the need of change and improvement for the study). Basically correlation and t-test analysis were used to test the hypothesis.

The organizational performances of Turkish top large firms were measured as perceived performance. Measurement of organizational performance in a perceived way has become a common type of methods in the area. Respondents were asked to compare the situation of the firms with the competitors for last two years for the topics below: The quality of the products, services of programs, development of new products, services or the programs, the ability to attract core employees to the firm, providing customer satisfaction, relations between management and employees, relations among employees, providing employee satisfaction, public image, efficiency of the employees, financial power, rate of increase in sales and income, general efficiency. The value of organizational performance is be calculated by taking the mean of the all performance questions.

The mean of the qualifications of the core employees which are in the frame of resource-based view is also calculated. The relation between the mean of the qualifications of the core employees and the mean for perceived organizational performance is presented by the results of the correlation analysis. The variables which were consisted in the research is also stated by the means of the questions it includes and these were put into statistical analysis. The results of the hypothesis were also be evaluated by the utilization of the correlation analysis.

To test the hypotheses developed between the couples of variables, a questionnaire as a method of data collection was conducted on a total of top 500 large firms of Turkey, between January to March 2012. The survey forms were firstly sent by e-mail. Then, due to very limited response rate, it was decided to send them by mail. Accordingly, survey forms, and a stamp affixed and address written envelope were put in an envelope and was sent. The questionnaire included a total of 67 items using 5-point Likert Scale. Also, survey form included 6 demographical questions. After conducting a pilot test on a group of 30 firms, it was decided to continue with the rest of the questionnaires, on the same sample. Data obtained from those 79 questionnaires analysed through the SPSS statistical package program, and 17 possible relations were tested.

The participants were from different sectors: 56 (70.9\%) manufacturing, 2 (2.5\%) mining, 15 (19\%) food, 4 (5.1\%) energy, and 2 (2.5) construction firms; as a total of 79 firms. The year of foundation changes between 1933 and 2007. Companies that are in the sample have headquarters in 23 different cities or provinces of Turkey. Accordingly, 24 of them (30.4\%) have headquarters in Istanbul, 8 of them (10.1\%) have headquarters in Izmir, 7 of them (8.9) have headquarters in Bursa, 6 of them (7.6\%) have headquarters in Gaziantep. In addition, Ankara, Kayseri, and Manisa provinces host 4 headquarters (5.1\%) each; and $15.3 \%$ in total. So, $27.7 \%$ of firms are located in some other provinces (Ordu, Adana, Konya, Sakarya, Kayseri, Malatya, Bolu, Kocaeli, Zonguldak, etc.). The ownership types of firms are: 5 of establishments (6.3\%) are public firm, and 74 of them $(93.7 \%)$ are private firms. On the other hand, in terms of the country of origin, 68 companies $(86.1 \%)$ are Turkish, 8 of firms $(10.1 \%)$ are owned by foreigners, and 3 of them (3.8\%) are joint ventures. Finally, as the "size" of organizations was taken as the number of employees, there were 27 firms which have less than 500 employees. 23 companies have employees changing from 500 to 1000 . Moreover, 23 firms have more than 1000 and less than 5000 employees. Also, 6 firms have more than 5000 employees.

\subsection{Measurement}

A total of 67 items included in the questionnaire are grouped under 11 variables. The variable of 'the value of core employees' is measured by 10 items, that of 'the rareness and inimitability of core employees' by 7 items, that of 'innovation' by 4 items, 'strategic vision' by 5 items, 'flexible design' by 5 items, 'quality management' by 5 items, 'organizational culture' 6 items, 'employee potential' 6 items, 'product diversity' 4 items, 'perceived 
organizational performance' 11 items and that of 'perceived market performance' by 4 items. According to the reliability tests conducted on these 11 variables, all the scales are found to be reliable (Cronbach's Alpha $>0.70$ ). In order to test the content validity of the scales used, the views by 4 academics from the same university were taken, and all the scales are also found to be valid by a mean of .90 agreement points by these academics.

\section{Results}

The impacts of the core employees on the perceived performances of the 500 largest Turkish firms were presented by the hypothesis above. The impact of the core employees of the organizational performance is the consequence of their importance for the firms. It is a realistic approach to expect that hypotheses will be supported by the statistical results. In a similar study of Genç (2009) about Turkish large firms demonstrated that there is a positive relationship between the superior qualifications of the employees as uniqueness, value, rareness, nonsubstitutability, and difficulty to replication and organizational performance. It is normal to achieve the similar findings for the core employees of Turkish large firms. It is a required behavior to focus on resource-based view especially for human resource management researches and implementations. Firms should keep the importance of the human resource on the agenda and try to improve it to gain competitive advantage. Implementing HRM activities that will facilitate achieving rare, valuable, nonsubstituble and inimitable human resource will provide an important advantage to the firms in this process.

Table 1 . The factor and reliability analyses of the variables

\begin{tabular}{|c|c|c|c|c|c|}
\hline Variable/Items & $\begin{array}{l}\text { Factor } \\
\text { Loadings }\end{array}$ & Alpha & $\mathrm{KMO}$ & $\begin{array}{l}\text { Barlett } \% \\
\text { Test (sig.) }\end{array}$ & $\begin{array}{l}\text { Explained } \\
\text { Variance }\end{array}$ \\
\hline Core Employees & & .8847 & .823 & .000 & 70.351 \\
\hline A3. Creative and bright. & .825 & & & & \\
\hline A6. Contribute efficiency and affectivity. & .806 & & & & \\
\hline A5. Develop knowledge, products. & .799 & & & & \\
\hline A9. Adequate skills for process development. & .793 & & & & \\
\hline A4. Expert on their jobs. & .779 & & & & \\
\hline Skills and Abilities of Core Employees & & .7857 & .702 & .000 & 70.348 \\
\hline $\begin{array}{l}\text { B2. It hard for our competitors to find these skills and expertise in } \\
\text { any other firm. }\end{array}$ & .856 & & & & \\
\hline $\begin{array}{l}\text { B3. It is hard to imitate these skills and expertise for our } \\
\text { competitors. }\end{array}$ & .778 & & & & \\
\hline B5. Provide competitive advantage to our firm. & .762 & & & & \\
\hline B1. Unique skills and abilities are special to our firm. & .693 & & & & \\
\hline Innovation & & .7482 & .750 & .000 & 58.889 \\
\hline C2. There are mechanisms to develop new ideas in our firm. & .833 & & & & \\
\hline C3. Teams have many skills/qualifications. & .822 & & & & \\
\hline C1. Our firm rewards creativity and respects it. & .743 & & & & \\
\hline $\begin{array}{l}\text { C4. It is easy to make resources harmonious as funds, tangible } \\
\text { elements, facilities, and information. }\end{array}$ & .659 & & & & \\
\hline Strategic Vision & & .8645 & .798 & .000 & 65.577 \\
\hline V5. Managers reward strategy related behaviors of employees. & .887 & & & & \\
\hline V1. Managers evaluate organizational strengths and weaknesses. & .872 & & & & \\
\hline $\begin{array}{l}\text { V2. Managers are classified through their uniqueness and their } \\
\text { contribution to organizational strength. }\end{array}$ & .837 & & & & \\
\hline V4. Business strategy is transformed to operational plans. & .798 & & & & \\
\hline V3. Managers look for compromise to implement planned strategy. & .626 & & & & \\
\hline Flexible Design & & .7453 & .713 & .000 & 57.314 \\
\hline F2. Our organizational culture supports change. & .838 & & & & \\
\hline F4. Decision making is decentralized in an advance level. & .795 & & & & \\
\hline $\begin{array}{l}\text { F3. Financial, physical, intangible resources and human resources } \\
\text { can be activated easily. }\end{array}$ & .716 & & & & \\
\hline F1. Jobs are designed in a flexible framework. & .667 & & & & \\
\hline Quality Management & & .8331 & .759 & .000 & 61.174 \\
\hline Q1. There is cooperation for quality in all levels of our firm. & .824 & & & & \\
\hline
\end{tabular}


Q4. Some methods as "brainstorming" are used to increase product $\quad .788$ quality.

Q3. Employees measure the quality of their jobs and record (note) $\quad .775$ it.

Q5. Employees analysis the quality of their outputs seriously.

Q2. Continues improvement is a key target for our organization.

G5. The behaviors of employees which are in harmony with .882

organizational culture are rewarded.

G1. Managers communicate to employees the shared values of organization.

G2. Employees can identify the shared values of organization and to be articulated to it.

G6. Managers support employees to achieve organizational purposes.

\section{Employee Potential}

H6. Work teams create a learning culture in organization. $\quad .805$

H1. Job analyses are important to employment. $\quad .796$

H2. Selection processes allow us to employ best personnel from .766 labor market.

H5. Organizational education is a beneficial tool to improve the skills and abilities of employees.

\section{Product Diversity}

K4. Product diversity is one of organizational priorities.

K1. Our firm operates in different areas.

K3. Products/services are different but related.

K2. As a result of organizational unity various products/services can be achieved with lower costs.

\section{Perceived Organizational Performance}

P5. Relations between management and other employees. $\quad .854$

P9. The efficiency of employees. $\quad .833$

P7. Personnel satisfaction. $\quad .824$

P10. Efficiency in general. $\quad .795$

$\begin{array}{ll}\text { P6. Relations between personnel, in general. } & .778\end{array}$

P3. The ability to attract core employees to firm. 743

Market Performance

$\begin{array}{llll}.7932 & .620 \quad 000 & 71.976\end{array}$

M2. Increase in sales. $\quad .920$

M3. Profitability $\quad .902$

M1. Marketing $\quad .706$

Note. $\mathrm{N}=79$.

Table 1 shows the factors of the variables. As it can be seen above, there are 11 variables, which their factors are demonstrated. The sub variables that have factor scores below .7 are excluded. The means of 11 variables were used to analyze the data. Smilarly, the alpha score is genereally high and above .70; which show a high reliability. The scales used in this research, were used in many other researchs, in other countries. 
Table 2. Correlations-1

\begin{tabular}{|c|c|c|c|c|c|c|c|c|}
\hline Variable & Mean & Standard Deviation & 1 & 2 & 3 & 4 & 5 & 5 \\
\hline 1.HRM Value & 3.870 & .634 & 1 & & & & & \\
\hline 2.HRM Uniqueness & 3.474 & .875 & $\begin{array}{c}.388^{* *} \\
.000\end{array}$ & 1 & & & & \\
\hline 4.Strategic Vision & 3.989 & .812 & $\begin{array}{c}.393 * * \\
.000\end{array}$ & $\begin{array}{l}.330 * * \\
.003\end{array}$ & $\begin{array}{l}.672 * * \\
.000\end{array}$ & 1 & & \\
\hline $\begin{array}{l}\text { 5.Organizational } \\
\text { Performance }\end{array}$ & 3.959 & .589 & $\begin{array}{c}.457^{* *} \\
.000\end{array}$ & $\begin{array}{c}.306 * * \\
.006\end{array}$ & $\begin{array}{l}.544 * * \\
.000\end{array}$ & $\begin{array}{c}.562 * * \\
.000\end{array}$ & 1 & \\
\hline 6. Market Performance & 4.054 & .625 & $\begin{array}{l}.141 \\
.216\end{array}$ & $\begin{array}{l}.135 \\
.235\end{array}$ & $\begin{array}{c}.273 * \\
.015\end{array}$ & $\begin{array}{c}.417^{* *} \\
.000\end{array}$ & $\begin{array}{c}.335^{* *} \\
.003\end{array}$ & 1 \\
\hline
\end{tabular}

Note. $* p<0.05 ; * * p<0.01 ; \mathrm{N}=79$.

As Table 2 shows there is a statistically significant relationship between the value of the human resources of the large firms of Turkey and their perceived organizational performances $(.457 ; .000)$. The level of the correlation is not high, but adequate to support the Hypothesis 6 (H6). There is a positive relationship between the high level qualifications of the core employees and the organizational performances of the Turkish large firms; as it was stated in the related hypothesis. This result reveals that, the high levels of intelligence, brightness, creativity, specialization, excellence, efficiency and all other skills, abilities and knowledge of the core employees of the Turkish large firms' employees has a scientifically significant affect on their perceived organizational performance. That result can not be seen for the relation between qualifications of the core employees and the market performances of the firms.

The results indicate that, the value of core employees is positively associated with the uniqueness of human capital $(.388 ; .000)$. In other words, $\mathrm{H} 1$ is supported. Therefore, the basic and general assumption based on value and uniqueness consistency gets scientifically significance in the frame of that sample.

It was also shown that the uniqueness of the core employees of Turkish large firms is positively and significantly related with the level of the perceived organizational performance $(.457 ; .000 ; .306 ; .006)$. This result supports the hypothesis $\mathrm{H} 2$ which claims there is a positive relationship between the qualifications of core employees in terms of value, rareness, inimitability, and organization and organizational performances of the Turkish large firms.

These two results also demonstrates consistency that, the qualifications of the core employees of Turkish large firms are significantly and positively related with the level of the perceived organizational performance, and also there is some evidence that the uniqueness of the core employees are significantly associated with the level of perceived organizational performance. In other words, both there is a clear support for the uniqueness of the core employees and organizational performance relationship there is a correlation between the value and the uniqueness of the core employees which can be assessed an indirect support Hypothesis 3 (H3).

Table 3. The result of test of homogeneity of variances

\begin{tabular}{llll}
\hline Levene Statistic & df1 & Df2 & Sig. \\
\hline 1,142 & 4 & 74 & .343 \\
\hline
\end{tabular}

Table 3 shows the result of the basic assumption of one-way ANOVA. The p value here (sig.) is bigger than 0.05 , which is .343 . According to this result, it can be said that variances are homogeneous. Therefore, it also can be estimated that, the results of variance analysis will be dependable.

Table 4. The result of one-way variance analysis (anova) tests

\begin{tabular}{llllll}
\hline & Sum of Squares & df & Mean Square & F & Sig. \\
\hline Between Groups & 1.203 & 4 & .301 & .736 & .570 \\
Within Groups & 30.240 & 74 & .409 & & \\
Total & 31.443 & 78 & & & \\
\hline
\end{tabular}


Table 4, demonstrates the one-way ANOVA results related with Hypothesis 3. As, p (sig.) value is bigger than 0.05 , the $\mathrm{H}_{0}$ is accepted. That is to say, the means of the value of core employees would not change according to industry type.

The results indicated the positive relationship between the value of core employees, and innovation implementations of Turkish large firms $(.594 ; .000)$, as a proof for H4a. It was also achieved that, the uniqueness and inimitability of core employees of Turkish large firms is statistically significantly related with innovation practices $(.341 ; .002)$, which is in the same direction with $\mathrm{H} 4 \mathrm{~b}$. So, this is the proof of the relation between uniqueness, rare skills and abilities and tradeable creativeness in the frame of the sample.

Table 5. Correlations for H5

\begin{tabular}{llll}
\hline & $\mathbf{1}$ & $\mathbf{2}$ & \\
\hline 1. Value of CEs & 1 & & \\
2. Uniqueness and Inimitability & $.338^{* *}$ & 1 \\
& .000 & $.238^{*}$ & 1 \\
3. Product Variety & $.320^{* *}$ & .035 \\
\hline
\end{tabular}

Note. ${ }^{* *}$ Correlation is significant at the 0.01 level (2-tailed).

* Correlation is significant at the 0.05 level (2-tailed).

As it can be seen at table 4 , the value of core employees are positively correlated $(.320 ; .000)$ with the product variety of Turkish large firms. Therefore, H5a is supported. Similarly, unique and inimitable HR of companies in the frame of the sample is positively and statistically significantly linked with product diversity $(.238 ; .035)$; which confirms H5b. However, the correlation results show a very low level link among variables. These results demonstrate how important the value, rareness, and inimitability of core employees are for the product diversity or product variety of firms. Accordingly, it can be claimed that, the qualifications of the core employees of firms might directly affect the range of output.

As Table 2 demonstrates, there is a statistically significant relation between the uniqueness of core employees, and organizational performance $(.306 ; .006)$. Besides, the statistically significant link between the value of core employees and organizational performance strengthens this finding $(.457 ; .000)$. Therefore, it is clear that, the qualifications of core employees are one of the main factors behind the success of those firms.

Table 6. Correlations-2

\begin{tabular}{|c|c|c|c|c|c|c|c|c|c|}
\hline Variable & Mean & $\begin{array}{l}\text { Standard } \\
\text { Deviation }\end{array}$ & 1 & 2 & 3 & 4 & 5 & 6 & 7 \\
\hline 1.Flexible Design & 3.316 & .757 & 1 & & & & & & \\
\hline 2.Quality & 4.222 & .739 & $.539 * *$ & 1 & & & & & \\
\hline Management & & & .000 & & & & & & \\
\hline 3.Organizational & 3.930 & .840 & $.532 * *$ & $.651 * *$ & 1 & & & & \\
\hline Culture & & & .000 & .000 & & & & & \\
\hline 4.Employee & 4.240 & .651 & $.285^{*}$ & $.535 * *$ & $.516^{* *}$ & 1 & & & \\
\hline Potential & & & 0.11 & .000 & .000 & & & & \\
\hline \multirow[t]{2}{*}{ 5.Product Diversity } & 3.057 & 1.214 & $.353 * *$ & $.279 *$ & $.320 * *$ & $.230^{*}$ & 1 & & \\
\hline & & & .001 & .013 & .004 & .041 & & & \\
\hline 6.Organizational & 3.959 & .589 & $.516^{* *}$ & $.576^{*}$ & $.565 * *$ & $.299 *$ & $.238 *$ & 1 & \\
\hline Performance & & & .000 & .000 & .000 & .007 & .034 & & \\
\hline 7.Market & 4.054 & .625 & $.326 * *$ & .056 & $.243^{*}$ & .183 & $.244^{*}$ & $.335^{*}$ & 1 \\
\hline Performance & & & .003 & .622 & .031 & .106 & .030 & .003 & \\
\hline
\end{tabular}

Note. $* p<0.05 ; * * p<0.01 ; \mathrm{N}=79$.

As it can be seen from Table 6, the flexible design, and the product variety of Turkish large firms are statistically significantly associated $(.353 ; .001)$. Accordingly, H7 was supported. By and large, flexible design results in creativeness; which is because of removing stress from skills and abilities, which make them more efficient. So, 
Turkish practice is in the same direction with this general identification. This result implies that the liberty which is about the opportunity to present the creativity, significantly affects the result.

Table 7. Correlation for $\mathrm{H} 9$

\begin{tabular}{lll}
\hline & 1. HRM Uniqueness & 2. Product Diversity \\
\hline 1. HRM Qualifications & 1 & \\
2. Organizational & $.437^{*}$ & 1 \\
Culture & .000 & \\
\hline
\end{tabular}

Note. $* *$ Correlation is significant at the .01 level. $\mathrm{N}=79$.

Table 7 shows the statistically significant relationship between the qualifications of core employees and organizational culture $(.437 ; .000)$, which supports H8. As organizational cultures include values or behavioral types, and ceremonies or rewards that shape the attitudes of employees, this association shows that these situations can be observed also in Turkish business practices.

Table 8. Correlations-3

\begin{tabular}{|c|c|c|c|c|c|c|c|c|}
\hline & $\mathrm{AB}$ & $\mathrm{G}$ & $\mathrm{V}$ & $\mathrm{H}$ & $\mathrm{F}$ & $\mathrm{K}$ & $\mathrm{C}$ & Q \\
\hline AB. Value and Rareness & 1 & & & & & & & \\
\hline \multirow[t]{2}{*}{ G. Organizational Culture } & $.414^{* *}$ & 1 & & & & & & \\
\hline & .000 & & & & & & & \\
\hline \multirow[t]{2}{*}{ V. Strategic Vision } & $.432 * *$ & $.813 * *$ & 1 & & & & & \\
\hline & .000 & .000 & & & & & & \\
\hline \multirow[t]{2}{*}{ H. Employee Potential } & $.489^{* *}$ & $.519^{* *}$ & $.552 * *$ & 1 & & & & \\
\hline & .000 & .000 & .000 & & & & & \\
\hline \multirow[t]{2}{*}{ F. Flexible Design } & $.330 * *$ & .532 & $.506 * *$ & $.296 * *$ & 1 & & & \\
\hline & .003 & .000 & .000 & .008 & & & & \\
\hline \multirow[t]{2}{*}{ K. Product Diversity } & $.332 * *$ & $.339 * *$ & $.288 * *$ & $.261^{*}$ & $.378 * *$ & 1 & & \\
\hline & .003 & .002 & .010 & .020 & .001 & & & \\
\hline \multirow[t]{2}{*}{ C. Innovation } & $.553 * *$ & $.750 * *$ & $.672 * *$ & $.470^{* *}$ & $.402 * *$ & $.359 * *$ & 1 & \\
\hline & .000 & .000 & .000 & .000 & .000 & .001 & & \\
\hline \multirow[t]{2}{*}{ Q. Quality Orientation } & $.545^{* *}$ & $.651^{* *}$ & $.570^{* *}$ & $.529 * *$ & $.539 * *$ & $.282 *$ & $.634 * *$ & 1 \\
\hline & .000 & .000 & .000 & .000 & .000 & .012 & .000 & \\
\hline
\end{tabular}

Note. ${ }^{* *}$ Correlation is significant at the 0.01 level (2-tailed). ${ }^{*}$ Correlation is significant at the 0.05 level (2-tailed); $\mathrm{N}=79$.

As it can be seen at Table 8, valuable and unique core employees are positively related with managerial capability for 'reinforcement of organizational culture' $(.414 ; .000)$; 'strategic vision' $(.432 ; .000)$; 'obtaining employee potential' (.489; .000); and 'flexible design' (.330; .003). Thus, H9a, H9b, H9c, and H9d are supported. These results demonstrate the consistency among variables. Also, this is the indication of the integration of core employees with these elements. Accordingly, valuable and unique core employees should be supported by organizational culture, which provides special conditions, and bases for characteristics for core employees. A strong organizational culture can facilitate strategy implementations, and achievement of organizational purposes. Thus, this estimation can be observed in the circumstances of Turkish large firms. Similarly, strategic vision can be determined, designed, and achieved by these types of employees. It can be said that, the qualifications of the core employees of Turkish large firms are consistent with strategic vision, and supporting it. Moreover, core employees can have higher levels of values and uniqueness by attracting more qualified personnel and retain them. In addition, flexible design would adapt firms to turbulent business environments, as it can be observed in Turkish practice.

As it is demonstrated at Table 8, valuable and unique core employees are positively related with the technical capability for 'innovation' $(.553 ; .000)$. Therefore, H10 is supported. Accordingly, it can be said that, Turkish companies depend their innovative activities on their valuable and unique core employees. This situation can be generalized worldwide, because of special knowledge, skills and abilities of these types of personnel. In other words, creativity can be sustained through these types of employees. 
Table 8 shows the significant and positive correlation between valuable and unique core employees and 'quality orientation' $(.545 ; .000)$. Similarly, valuable and unique core employees are significantly and positively associated with 'product diversity' (.332; .003). Therefore, both H11a, and H11b are supported.

\section{Discussion}

The analysis of the data revealed that, the value of core employees of Turkish large firms is positively associated with the uniqueness of their human capital $(.388 ; .000)$. So, it can be said that qualifications of core employees are consistent. Accordingly, these large firms of Turkey, which generally have competitive advantages, originate from both unique and rare core employees and other sources or conditions, factors. In addition, this result can also be taken as a proof for the consistency in the data set. So, valuable core employees would facilitate to achieve the purposes of an organization, such as competitive advantage. At the same time, it is clear that, the relatively low level of correlation demonstrates value and uniqueness can not be seen together in some firms for their core employees.

Turkish large firms have qualified employees, who graduated from the popular universities of Turkey or other countries. In other words, Turkish labor force becoming more and more educated day by day. These generally well educated personnel are one of the basic sources of competitive advantage for Turkish large firms. Therefore, the increasing power of Turkish large firms should mainly be originated from these types of personnel, who have high levels of knowledge, skills, and abilities.

It was also achieved that, the qualifications of core employees in terms of value, rareness, inimitability and organization and the performances of Turkish large firms, which are in the sample, are significantly and positively correlated. This is the main finding of this research. As consistent with all expectations, core employees have an important impact on organizational performances. Although, the value of core employees does not change due to industry type, performance related result is so dominant and general. Although, every industry needs, so employs special types of human resource, basic characteristics of them would not change. In other words, value and rareness would not change according to the industries. The level of association between value and performance $(.457 ; .000)$, or rareness and performance $(.306 ; .006)$ can be compared. So, this situation can be explained as, core employee value have higher impact on organizational performance than uniqueness.

It was also found that, the means of the value of core employees do not change according to industry type. This result shows that, Turkish large firms employ core employees who have similar levels of value and uniqueness. In general, large firms recruit personnel who have high level of qualifications. This can be related to the financial capabilities of these types of firms. Moreover, their vision and purposes require these types of HR practices. Also, it can be said that, business environment forces firms to employ sophisticated personnel to maintain their competitiveness and achievements.

The results of the analysis indicate that, the characteristics of core employees as value, rareness, and inimitability significantly and positively associated with innovation implementations, and product variety of Turkish large firms. This result is also consistent with the basic idea of this research. Accordingly, the value of core employees $(.594 ; .000)$, and uniqueness and inimitability of core employees $(.341 ; .002)$ have significant impacts on innovative activities. Similarly, value $(.320 ; .000)$, and uniqueness and inimitability $(.238 ; .035)$ are associated with product variety. Yet, the value has higher levels of impacts than uniqueness and inimitability. Thus, again at this point, value has higher levels of impact than uniqueness and inimitability. This result can be the indication of dependence of Turkish large firms for innovation on value than uniqueness and inimitability. Also, in general, the mean of value (3.870) is higher than the mean (3.474) of uniqueness and inimitability, which support previous comments.

The analysis of the data shows that, high level qualifications of the core employees and the organizational performances are significantly and positively associated. Accordingly, value $(.457 ; .000)$, and the uniqueness $(.306 ; .006)$ of core employees are associated with organizational performance. This is one of the main findings of this research. This result shows the importance of core employees for Turkish large firms. Moreover, organizational performances depend mainly on value than uniqueness and inimitability.

As supporting each other, flexible design is also significantly and positively associated with product variety $(.353 ; .001)$. More than that, these are two integrated variables too. So, this result also demonstrates this reality. As it can be seen in many western countries, product variety requires a flexible organizational structure to strengthen creativity.

The qualifications of core employees are significantly and positively associated with organizational culture (.437; .000). Accordingly, organizational culture should support organizational strategy. So, cultures should 
include values that facilitate strategy design and implementation. In general, cultures should be consistent with strategies, or support strategic changes. These findings reveal the reality that, the core employees of Turkish firms should be feed by organizational cultures.

Another set of findings are, valuable and unique core employees are positively related with managerial capability for 'reinforcement of organizational culture' $(.414 ; .000)$; 'strategic vision' $(.432 ; .000)$; 'obtaining employee potential' $(.489 ; .000)$.

The results of the analysis demonstrate that, valuable and unique core employees are significantly and positively associated with the managerial capabilities of 'reinforcement of organizational culture', 'strategic vision', and 'obtaining employee potential'. Accordingly, this is the indication of the complexity of an organizational and managerial structure and the position of core employees in these variables.

A powerful organizational culture should be constructed through human resource that is highly qualified. Therefore, communicating organizational values to employees, integrating them to these values is so essential to set up strong organizational cultures. Similarly, the behaviors or activities of personnel, so core employees, would be in accordance with organizational values and principles. Moreover, behaviors which are consistent with organizational culture should be rewarded. In addition, management should provide support to these types of employees.

Management should asses the opportunities and threats of business environment. Moreover, management should look for compromise for the implementation of organizational strategy. Similarly, business strategy should be divided into operational plans. And also, managers should reward employees for their behaviors, which are in accordance with organizational strategy.

A properly designed, and motivating strategic vision would made it easier to set up adequate strategies. By this way, organizations can implement efficient methods, to achieve levels such as competitive advantage. A well established vision can strengthen unity for company purposes, and stimulate especially internal stakeholders for them. As it can be observed in Turkish practice, the core employees of an organization would be more productive, and would contribute to organizational performance with a well-articulated strategic vision.

Attracting the core employees who are valuable, unique, and inimitable is important to achieve competitive advantage. Therefore, recruitment should be realized with job analysis. Selection process should be made it possible to obtain best employees from labor market. Equally, employees should be paid and rewarded through his or her contribution to organization. Similarly, organizational educating should be used as a tool. In Turkey, large firms have very sophisticated selection or recruitment process. So, these types of firms can employ best core employees from the labor market.

The valuable and unique core employees are positively related with managerial capability for 'flexible design' $(.330 ; .003)$. These types of employees are positively associated with the managerial capability for 'flexible design'. Equally, the technical capabilities of 'innovation', and output-based capability of 'quality orientation', and 'product diversity' are significantly and positively correlated with the valuable and unique core employees.

The valuable and unique core employees are positively related with the technical capability for 'innovation' $(.553 ; .000)$. The valuable and unique core employees are correlated with 'quality orientation' $(.545 ; .000)$. Similarly, valuable and unique core employees are significantly and positively associated with 'product diversity' $(.332 ; .003)$. As value has a level of mean which is higher than uniqueness and inimitability, at this point these two types of variables are integrated, and analyzed as one variable. As consistent with proposals, the valuable and unique core employees of Turkish large firms are innovative and quality oriented. Interestingly, there is a low association between value and uniqueness, and 'product diversity'.

\section{Conclusion}

This paper has mainly investigated the relation between the qualities of core employees and organizational performance, and has shown that, these two types of variables are significantly and positively related. It was also shown that, there is a positive relation between the characteristics as value, rareness, and inimitability of core employees, and innovation implementations, and product variety of Turkish large firms. These results have revealed the importance of core employees, and their effect on the organizational performances of Turkish large firms. Further research, should focus and investigate the level of impact of core employees in different industries, and sizes.

As consistent with hypothesis, flexible design and product variety are significantly and positively associated. Flexible design is needed for organizations which employ personnel that have high level of qualities, or who are valuable, rare, and inimitable. Accordingly, flexible design, would lead properly organized core employees. 
The results indicated that, valuable and unique core employees are positively related with the managerial capacity for 'flexible design'; output-based capability for 'quality orientation'; and output-based capability for 'product diversity'.

The results have also shown that, the value of core employees is more effective than uniqueness or inimitability in Turkish large firms. In other words, innovation or product variety is being depended on value than rareness. Therefore, it can be said that, maintaining current conditions or imitating can be more important than creating, in some companies. So, for these types of organizations, 'new' reflects the 'new for firm', not for the market.

This study may enhance the understanding the importance of core employee and extend the concept while relating it with the organizational performance. Organizations should realize the importance of core employees for their achievements. Accordingly, human resource management activities such as selection, recruitment, educating and development, wage and salaries, performance appraisal need to be implemented with special methods for core employees or candidate core employees.

\section{References}

Atchison, T. J. (1991). The employment relationship: Un-tied or re-tied? Academy of Management Executive, $5(4), 52-62$.

Barney, J. B. (1986). Organizational culture: can it be the source of sustained competitive advantage? Academy of Management Review, 11(3), 656-665. http://dx.doi.org/10.5465/AMR.1986.4306261

Barney, J. B. (1991). Firm resources and sustained competitive advantage. Journal of Management, 17(1), 99-120. http://dx.doi.org/10.1177/014920639101700108

Barney, J. B. (1995). Looking inside for competitive advantage. Academy of Management Executive, 9(4), 49-61.

Barney, J. B., \& Wright, P. M. (1998). On becoming a strategic partner :the role of human resources in gaining competitive advantage. Human Resource Management, 37(1), 31-46. http://dx.doi.org/10.1002/(SICI)1099-050X(199821)37:1<31::AID-HRM4>3.0.CO;2-W

Barney, J. B. (2001). Is resource-based view a useful perspective for strategic management research? Yes. Academy of Management Review, 26(1), 41-55.

Beardwell, J., \& Claydon, T. (2011). Strategic human resource management from human resource management: A contemporary approach. In C. Woodshams (Edt., comp.), Human Resource Management (pp. 60-111). Essex, Great Britain: Pearson.

Boxall, P. (1996). The strategic HRM debate and the resource based view of the firm. Human Resource Management Journal, 6(3), 59-75. http://dx.doi.org/10.1111/j.1748-8583.1996.tb00412.x

Certo, S. C. (1997). Modern management-diversity, quality, ethics, and the global environment (7th ed.). New Jersey, USA: Prentice-Hall Environment.

Cook, C. W., \& Hunsaker, P. L. (2001). Management and organization behavior (3rd ed.). New York, USA: McGraw-Hill/Irwin Publications.

Collis, D., \& Montgomery, C. (1995). Competing on resources: Strategy in the 1990's. Harvard Business Review, $76(3), 118-128$.

Delaney, J. T., \& Huselid, M. A. (1996). The impact of human resource management practices on perceptions of organizational performance. Academy of Management Journal, 39(4), 949-969. http://dx.doi.org/10.2307/256718

Dierickx, I., \& Cool, K. (1989). Asset stock accumulation and sustainability of competitive advantage. Management Science, 35, 1504-1511. http://dx.doi.org/10.1287/mnsc.35.12.1504

Erdil, O., Kitapçı, H., \& Timurlenk, B. (2010). Effects of core employees on organizational capabilities and firm performance. Journal of Global Strategic Management, 7, 30-38.

Eren, E. (2002). Stratejik yönetim ve işletme politikası (6th ed.). Istanbul: Beta Basım Yayım ve Dağıtım.

Genç, K. Y. (2009). Strategic human resource management - organizational performance relationship and an application on Turkish large firms (Unpublished Doctoral Dissertation in Turkish), Karadeniz Technical University, Trabzon, Turkey.

Hamel, G., \& Prahalad, C. (1993). Strategy as Stress and Leverage. Harvard Business Review, 71(2), 75-84. 
Harel, G. H., \& Tzafrir, S. S. (1999). The effect of human resource management practices on the perceptions of organizational and market performance of the firm. Human Resource Management, 38(3), 185-200. http://dx.doi.org/10.1002/(SICI)1099-050X(199923)38:3<185::AID-HRM2>3.0.CO;2-Y

Hendersen, R., \& Cockburn, I. (1994). Measuring competence? Exploring firm effects in pharmaceutical research. Strategic Management Journal, 15, 63-84. http://dx.doi.org/10.1002/smj.4250150906

Hester, L. J. (2005). The impact of strategic human resource management on organizational performance: A perspective of the resource-based view of the firm (Unpublished Doctoral Dissertation), Nova Southeastern University, USA.

Kreitner, R., \& Kinicki, A. (2004). Organizational behavior (6th ed.). New-York, USA: McGraw-Hill Publications.

Lado, A. A., Boyd, N. G., \& Wright, P. (1992). A competency-based model of sustainable competitive advantage: toward a conceptual integration. Journal of Management, 18(1), 77-91. http://dx.doi.org/10.1177/014920639201800106

Lado, A. A., \& Wilson, M. C. (1994). Human resource systems and sustained competitive advantage: A competency based perspective. Academy of Management Review, 19(4), 699-727.

Lepak, D. P., \& Snell, S. A. (2002). Examining the human resource architecture: The relationships among human capital, employment and human resource configuration. Journal of Management, 28, 517-543. http://dx.doi.org/10.1016/S0149-2063(02)00142-3

Lepak, D. P., Takeuchi, R., \& Snell, S. A. (2003). Employment flexibility and firm performance: Examining the interaction effects of employment mode, environmental dynamism, and technological intensity. Journal of Management, 29(5), 681-703. http://dx.doi.org/10.1016/S0149-2063(03)00031-X

Ligun, W. (2004). An examination of strategic human resource management and firm performance in Chine (Unpublished Doctoral Dissertation). Chinese University of Hong Kong, Hong Kong, China People's Republic.

Lopez-Cabrales, A., Valle, R., \& Herrero, I. (2006). The contribution of core employees to organizational capabilities and efficiency. Human Resource Management, 45(1), 81-109. http://dx.doi.org/10.1002/hrm.20094

Lundy, O., \& Cowling, A. (1996). Strategic human resource management (1st ed.). Great Britain: Routledge.

Macduffie, J. P. (1995). Human resource bundles and manufacturing performance: Organization logic and flexible production systems in the world auto industry. Industrial and Labor Relations Review, 48(2), 197-221. http://dx.doi.org/10.2307/2524483

Mello, J. A. (2006). Strategic human resource management (2nd ed.). USA: South Western (Thompson Corporation).

Mullins, L. J. (2002). Management and organizational behavior (6th ed.). London, England: Prentice Hall Publications.

Nadler, D., \& Tushman, M. (1999). The organization of the future: Strategic imperatives and core competencies for the $21^{\text {st }} \quad$ century. Organizational Dynamics, 28(1), $45-60$. http://dx.doi.org/10.1016/S0090-2616(00)80006-6

Osterman, P. (1994). How common is workplace transformation and who adapts it? Industrial \& Labor Relations Review, 47, 173-190. http://dx.doi.org/10.2307/2524415

Prahalad, C. K., \& Hamel, G. (1990). The core competence of the corporation. Harvard Business Review, May-June.

Reed, R., \& DeFillipyi, R. (1990). Causal ambiguity, barriers to imitation and sustained competitive advantage. Academy of Management Review, 15, 88-102.

Schermerhon, Jr., J. R., \& Hunt, J. G. (2000). Organizational behavior (7th ed.). USA: Wiley Publications.

Snell, S. A., \& Dean, JR, J. W. (1992). Integrated manufacturing and human resource management: A human capital perspective. Academy of Management Journal, 35(3), 467-504. http://dx.doi.org/10.2307/256484

Snell, S. A., Youndt, M., \& Wright, P. (1996). Establishing a framework for researching in strategic human resource management: Merging resource theory and organizational learning. Research in Personnel \& Human Resource Management, 14, 61-90. 
Teece, D., Pisano, G., \& Shuen, A. (1997). Dynamic capabilities and strategic management. Strategic Management Journal, $18, \quad 509-533$. http://dx.doi.org/10.1002/(SICI)1097-0266(199708)18:7<509::AID-SMJ882>3.0.CO;2-Z

Takeuchi, R. (2003). How do we get from there to here? Understanding the black box in strategic HRM research resource-based and social exchange perspectives (Unpublished Doctoral Thesis). The University of Maryland, Maryland, USA.

Ulrich, D. (1994). Profiling organizational competitiveness: cultivating capabilities. Human Resource Planning, 16(3), 1-17. http://dx.doi.org/10.1002/hrm.3930330102

Ülgen, Hayri, \& Mirze, K. S. (2004). İsletmelerde stratejik yönetim (2nd ed.). Istanbul, Turkey: Literatur.

Wernerfelt, B. (1984). A reseorce-based view of the firm. Strategic Management Journal, 5, 171-180. http://dx.doi.org/10.1002/smj.4250050207

Willcoxson, L., \& Millet, B. (2000). The management of organizational culture. Australian Journal of Management \& Organizational Behaviour, 3(2), 91-99.

Wright, P. M., \& Snell, S. A. (1991). Toward an integrative view of strategic human resource management. Human Resource Management, 1(3), 203-225. http://dx.doi.org/10.1016/1053-4822(91)90015-5

Wright, P. M., \& McMahan, G. C. (1992). Theoretical perspectives of strategic human resource management. Journal of Management, 18(1), 295-320. http://dx.doi.org/10.1177/014920639201800205

Wright, P. M., McMahan, G. C., MacWilliams, A. (1993). Human resources and sustained competitive advantage: A resource-based perspective. International Journal of Human Resource Management, 5, 301-326. http://dx.doi.org/10.1080/09585199400000020

Wright, P. M., Kroll, M. J., \& Parnell, J. A. (1998). Strategic management, concepts and cases. New Jersey, USA: Prentice-Hall, Inc.

Youndt, M. A., Snell, S. A, Dean, Jr. J. W., \& Lepak, D. P. (1996). Human resource management, manufacturing strategy, and firm performance. Academy of Management Journal, 39(4), 836-866. http://dx.doi.org/10.2307/256714

Youndt, M. A. (1998). Human resource management systems, intellectual capital and organizational performance (Unpublished Doctoral Dissertation). The Pennsylvania State University, Pennsylvania, USA.

\section{Copyrights}

Copyright for this article is retained by the author(s), with first publication rights granted to the journal.

This is an open-access article distributed under the terms and conditions of the Creative Commons Attribution license (http://creativecommons.org/licenses/by/3.0/). 